\title{
Insulin Receptor and IRS-1 Co-immunoprecipitation with SOCS-3, and IKKa/ $\beta$ Phosphorylation are Increased in Obese Zucker Rat Skeletal Muscle
}

\author{
ILYA A. ZOLOTNIK, TANIA Y. FIGUEROA, and BEN B. YASPELKIS III \\ Exercise Biochemistry Laboratory, Department of Kinesiology, California State University \\ Northridge, CA 91330 USA
}

\section{Abstract}

\begin{abstract}
Aims-We evaluated if select pro-inflammatory cytokines and/or the protein suppressor of cytokine signaling 3 (SOCS-3) could account for decreased insulin-stimulated phosphatidylinositol 3-kinase (PI3-K) activity in the skeletal muscle of the obese Zucker rat.
\end{abstract}

Main Methods-Eight lean and eight obese Zucker rats $\sim 4$ wk of age were obtained and allowed to feed ad libitum for $4 \mathrm{wk}$ before undergoing hind limb perfusion in the presence of $500 \mu \mathrm{U} / \mathrm{ml}$ insulin.

Key Findings-Insulin-stimulated skeletal muscle PI3-K activity and 3-O-methylglucose transport rates were reduced $(\mathrm{P}<0.05)$ in obese compared to lean animals. IRS-1 concentration remained unchanged although IRS-1 tyrosine phosphorylation was decreased $(\mathrm{P}<0.05)$, and IRS-1 serine phosphorylation $(\mathrm{pS})$ was increased $(\mathrm{P}<0.05)$ in obese animals compared to lean animals. $\mathrm{IKKa} / \beta \mathrm{pS}$ and JNK theronine/tyrosine phosphorylation was increased $(\mathrm{P}<0.05)$ in the obese animals. I $\kappa \mathrm{Ba}$ concentration was decreased $(\mathrm{P}<0.05)$ and I $\kappa \mathrm{Ba} \mathrm{pS}$ was increased $(\mathrm{P}<0.05)$ in the obese compared to lean Zucker animals. SOCS-3 concentration and SOCS-3 coimmunoprecipitation with both insulin receptor $\beta$-subunit (IR- $\beta$ ) and IRS-1 were elevated $(\mathrm{P}<0.05)$ in obese compared to lean animals. IRS- 1 co-immunoprecipitation with IR- $\beta$ was reduced $56 \%$ in the obese animals.

Significance-Increased IKKa $/ \beta$ and JNK serine phosphorylation may contribute to increasing IRS- 1 serine phosphorylation, while concurrent co-localization of SOCS-3 with both IR- $\beta$ and IRS-1 may prevent IRS-1 from interacting with IR- $\beta$. These two mechanisms thusly may independently contribute to impairing insulin-stimulated PI3-K activation in the skeletal muscle of the obese Zucker rat.

(C) 2012 Elsevier Inc. All rights reserved.

Address correspondence to: Ben B. Yaspelkis III, Ph.D., Department of Kinesiology, California State University Northridge, 18111 Nordhoff Street, Northridge, CA 91330-8287 USA, Phone: 818-677-7509, Fax: 818-677-7514, ben.yaspelkis@ csun.edu.

\section{AUTHOR CONTRIBUTIONS}

Conception and design of the experiments: Ben B. Yaspelkis III

Collection, analysis and interpretation of data: Ilya A. Zolotnik, Tania Y. Figueroa, Ben B. Yaspelkis III

Drafting the article or revising it critically for important intellectual content: Ilya A. Zolotnik, Ben B. Yaspelkis III

There are no conflicts of interests associated with this paper by the authors.

Publisher's Disclaimer: This is a PDF file of an unedited manuscript that has been accepted for publication. As a service to our customers we are providing this early version of the manuscript. The manuscript will undergo copyediting, typesetting, and review of the resulting proof before it is published in its final citable form. Please note that during the production process errors may be discovered which could affect the content, and all legal disclaimers that apply to the journal pertain. 


\section{Keywords}

Insulin signaling; PI3-K activity; insulin resistance

\section{INTRODUCTION}

It is well established that in the high-fat fed rat, an environmental model of insulin resistance, that insulin-stimulated skeletal muscle carbohydrate metabolism is significantly impaired as evidenced by decreased rates of 3-O-methyl glucose (3-MG) transport (Hansen et al., 1998; Krisan et al., 2004; Singh et al., 2003; Yaspelkis et al., 2001; Yaspelkis et al., 2009; Yaspelkis et al., 2007) and phosphatidylinositol 3-kinase (PI3-K) activity (Lessard et al., 2007; Singh et al., 2003; Yaspelkis et al., 2009). We have previously reported that insulin-stimulated plasma membrane-associated atypical PKC zeta (aPKC $\zeta$ ) and atypical PKC lambda (aPKC $\lambda$ ) protein concentration and activity, and cytosolic Akt 2 and aPKC $\zeta / \lambda$ activities are reduced in the skeletal muscle of the high fat fed rat (Herr et al., 2005; Lessard et al., 2007). While activation of these downstream components of the insulin signaling cascade were reduced by high fat feeding it appeared that the impairments were largely a result of an insufficient activation of PI3-K. Based on this observation it was of interest to ascertain if a mechanism could be identified that could account for why the provision of a high fat diet decreased insulin stimulated PI3-K activity.

We have evaluated whether suppressor of cytokine signaling 3 (SOCS-3) could account for the reduced insulin-stimulated PI3-K activity in the high fat-fed rodent (Yaspelkis et al., 2009). Our interest in this molecule as a potential modulator of PI3-K activity was based on reports that SOCS-3 is elevated in adipocytes and hepatocytes obtained from ob/ob and db/ db mice (Emanuelli et al., 2001; Ueki et al., 2004b), while in high fat-fed rodent skeletal muscle SOCS-3 mRNA (Steinberg et al., 2004) and protein concentration (Ropelle et al., 2006) are also elevated. We observed that SOCS-3 protein concentration was elevated in the skeletal muscle of the high-fat fed animals and that there was significantly greater coimmunoprecipitation of SOCS-3 with the insulin receptor $\beta$ (IR- $\beta$ ) subunit and insulin receptor substrate 1 (IRS-1) in the high-fat fed skeletal muscle that possibly resulted in a physical barrier that impaired IRS- 1 from interacting with the IR- $\beta$ subunit. It has also been noted that a component of the pro-inflammatory cascade, I $\mathrm{KB}$ kinase beta (IKK $\beta$ ), when activated directly phosphorylates IRS-1 on serine 307 (Gao et al., 2002). This is of interest as it has been reported that increased IRS-1 serine phosphorylation prevents the insulin signaling cascade from becoming fully activated (Hirosumi et al., 2002; Kim et al., 2004; Um et al., 2004; Yu et al., 2002). In the high-fat fed rat we have also recently found that components of the pro-inflammatory pathway are activated (Yaspelkis et al., 2009). In particular, IKK serine phosphorylation was increased which may have contributed to increased IRS-1 serine phosphorylation, and in turn prevented PI3-K from being fully activated.

The obese Zucker rat, a well studied genetic model of insulin resistance, also exhibits decreased rates of insulin-stimulated skeletal muscle 3-MG transport (Banks et al., 1992) and PI3-K activity (Christ et al., 2002; Kim et al., 2000). Similar to the high-fat fed rat, the obese Zucker rat exhibits reduced IR- $\beta$ phosphorylation and IRS- 1 tyrosine phosphorylation while showing increased IRS-1 serine phosphorylation leading to impaired PI3-K activity in the skeletal muscle (Christ et al., 2002; Jiang G et al., 2002; Kim et al., 2000). This raises the possibility that those factors we have noted that contribute to decreased IRS- 1 tyrosine phosphorylation and reduced PI3-K activity in the high-fat fed rat may also contribute in a similar manner to impairing PI3-K activation in the skeletal muscle of the obese Zucker rat. Moreover, as the male Zucker rat represents a more severe model of insulin resistance than 
the high fat-fed rat, we believed that the approach we utilized in the present investigation might allow for a better understanding of potential mechanisms that lead to impaired insulin signaling in skeletal muscle. Consequently, the aims of this investigation were to identify whether, in the skeletal muscle of the obese Zucker rat, 1) SOCS-3 protein expression is elevated, 2) SOCS-3 co-immunoprecipitation with the IR- $\beta$ and IRS-1 is increased and 3 ) select inflammatory pathways components are activated and contribute to inhibiting the activation of PI3-K.

\section{MATERIAL AND METHODS}

\section{Experimental Design}

Eight lean male Zucker rats and eight obese Zucker rats $\sim 4$ wk old were obtained from Charles River Laboratories (Wilmington, MA) and placed on rat chow (LabDiet 5001, PMI Nutrition International Inc., Brentwood, MO). Animals were allowed to feed ad libitum for 4 wk. Animals were housed two per cage in a temperature-controlled environment at $21^{\circ} \mathrm{C}$ with an artificial 12-12 $\mathrm{h}$ light-dark cycle. Animals were fasted for 8-12 $\mathrm{h}$ prior to undergoing hind limb perfusion.

All experimental procedures were approved by the Institutional Animal Care and Use Committee at California State University, Northridge and conformed to the guidelines for the use of laboratory animals published by the US Department of Health and Human Resources.

\section{Surgical Preparation and Hind Limb Perfusions}

Animals were anesthetized with an intraperitoneal injection of sodium pentobarbital (6.5 $\mathrm{mg} / 100 \mathrm{~g}$ body wt) and surgically prepared for hind limb perfusion as previously described by Ruderman et al. (Ruderman et al., 1971) and modified by Ivy et al. (Ivy et al., 1989). Following surgical preparation, red (RG) gastrocnemius and red (RQ) quadriceps were harvested from the left hind limb. Cannulas were inserted into the abdominal aorta and vena cava, and the animals were sacrificed via an intracardiac injection of pentobarbital as the hind limbs were washed out with $30 \mathrm{ml}$ of Krebs-Henseleit buffer ( $\mathrm{pH}$ 7.55). Immediately the cannulas were placed in line with a nonrecirculating perfusion system as the right hind limb was allowed to stabilize during a $5 \mathrm{~min}$ washout period. The perfusate was continuously gassed with a mixture of $95 \% \mathrm{O}_{2}-5 \% \mathrm{CO}_{2}$ and warmed to $37^{\circ} \mathrm{C}$. Perfusate flow rate was set at $7.5 \mathrm{ml} / \mathrm{min}$ during the stabilization and subsequent perfusion, during which rates of glucose transport were determined.

Perfusions were performed in the presence of $500 \mu \mathrm{U} / \mathrm{ml}$ insulin. The basic perfusate medium consisted of 30\% washed time-expired human erythrocytes (Ogden Medical Center, Ogden, UT), KHB, 4\% dialyzed bovine serum albumin (Cat\# BAC62-1000, Equitech-Bio Inc, Kerrville, TX), and $0.2 \mathrm{mM}$ pyruvate. Fatty acids and native sialic acids are preserved in the BSA. The hind limbs were washed out with perfusate containing $1 \mathrm{mM}$ glucose for 5 $\mathrm{min}$ in preparation for the measurement of glucose transport. Glucose transport was measured over an 8-min period using an $8 \mathrm{mM}$ concentration of non-metabolized glucose analog 3-O-methylglucose (3-MG; $32 \mu \mathrm{Ci} 3-\left[{ }^{3} \mathrm{H}\right] \mathrm{MG} / \mathrm{mM}$, PerkinElmer Life Sciences, Boston, MA) and $2 \mathrm{mM}$ mannitol $\left(60 \mu \mathrm{Ci}-\left[1-{ }^{14} \mathrm{C}\right] \mathrm{mannitol} / \mathrm{mM}\right.$, PerkinElmer Life Sciences). Rates of insulin stimulated skeletal muscle 3-MG transport were calculated as previously described (Krisan et al., 2004; Yaspelkis et al., 2001; Yaspelkis et al., 2004). Immediately after the transport period portions of the RG and RQ were excised from right hind limb, blotted on gauze dampened with cold Krebs-Henseleit buffer, freeze clamped in liquid $\mathrm{N}_{2}$ and stored at $-80^{\circ} \mathrm{C}$ for later analysis. The $\mathrm{RG}$ was utilized in the analysis of the 
insulin signaling cascades, while the RQ was used to assess SOCS-3 and select components of the pro-inflammatory signaling cascade.

\section{Muscle Lysate Preparation}

Muscle samples were weighed and homogenized 1:10 in homogenization buffer that contained $50 \mathrm{mM}$ Hepes, $150 \mathrm{mM} \mathrm{NaCl}, 200 \mathrm{mM}$ sodium pyrophosphate, $20 \mathrm{mM} \mathrm{a}$ glycerolphosphate, $20 \mathrm{mM} \mathrm{NaF}, 2 \mathrm{mM}$ sodium vanadate, $20 \mathrm{mM}$ EDTA, 1\% IGEPAL, $10 \%$ glycerol, $2 \mathrm{mM}$ phenylmethylsulfonyl fluoride, $1 \mathrm{mM} \mathrm{MgCl}_{2}, 1 \mathrm{mM} \mathrm{CaCl}_{2}, 10 \mu \mathrm{g} / \mathrm{ml}$ leupeptin, and $10 \mu \mathrm{g} / \mathrm{ml}$ aprotinin. Muscles were homogenized on ice using a glass pyrex homogenizer and centrifuged at $18,300 \times \mathrm{g}$ for $15 \mathrm{~min}$ at $4^{\circ} \mathrm{C}$ (Micromax RF, International Equipment Co., Needham Heights, MA). The supernatant was collected and quantified for protein content by the Bradford Method using a Benchmark microplate reader (BioRad, Richmond, CA).

\section{Insulin Signaling Cascade}

Western Blotting-Insulin receptor- $\beta$ subunit (IR- $\beta$ ) and IRS-1 protein concentration was determined using lysate samples. Samples were combined (1:1) with Laemmli sample buffer and heated at $100^{\circ} \mathrm{C}$ for 5 minutes. Seventy micrograms of muscle lysate protein were subjected to sodium dodecyl sulfate-polyacrylamide gel electrophoresis (SDS-PAGE) run under reducing conditions on $10 \%$ resolving gels (IR- $\beta$ ) or $7.5 \%$ (IRS-1) using a MiniProtean III dual slab cell (BioRad). Resolved gels were equilibrated in a Bjerrum and Schafer-Nielson Transfer Buffer for $30 \mathrm{~min}$. Resolved proteins were then transferred to Polyvinylidene difluoride (PVDF) membranes using a semidry transfer unit (10 V for 30 min). The membranes were blocked in 5\% non-fat dry milk-Tween 20 tris buffered saline (NFDM-TTBS) blocking solution and then incubated with either affinity purified rabbit polyclonal anti-IR- $\beta$ (Cat\# 07-724, Millipore Corporation, Temecula, CA) or anti-IRS-1 (Cat\# 06-526, Millipore).

For these proteins, and all others in which we utilized Western blotting, we proceeded in the following manner. The membrane was then incubated with a species specific secondary antibody conjugated to HRP. Antibody binding was visualized using enhanced chemiluminescence in accordance to the manufacturer's instructions. Images were captured using a ChemiDoc system (BioRad) equipped with a charge-coupled device camera and saved to a computer. Bands were quantified using Quantity One analysis software (BioRad). Each gel contained samples from both experimental groups, the density of the bands was determined and the data were expressed as a percentage of a standard muscle sample run on each gel such that comparisons could be made across gels. The autoradiographs presented were selected from samples that best reflected the mean of the experimental group.

\section{IR- $\beta$ Tyrosine Phosphorylation, IRS-1 Tyrosine Phosphorylation, and IRS-1} Serine Phosphorylation-Phosphorylation of the IR- $\beta$ subunit and IRS-1 was determined using immunoprecipitation followed by Western blotting. Lysate protein samples (500 $\mu \mathrm{g}$ for IR- $\beta \mathrm{pY}, 500 \mu \mathrm{g}$ for IRS-1 pY and $800 \mu \mathrm{g}$ for IRS-1 pS 307) were incubated with $4 \mu \mathrm{g}$ of either anti-IR- $\beta$ subunit (Cat \#6-492, UBT) or anti-IRS-1 (Cat\# $6-248$, UBT) at $4^{\circ} \mathrm{C}$. Following an overnight incubation, $80 \mu \mathrm{l}$ of Protein-A sepharose Type CL-4B (PRO-A; Cat\#17-0789-01; GE HealthCare, Piscataway, NJ) bead slurry were added to the samples and incubated for 1.5 hours at $4^{\circ} \mathrm{C}$ with rotation. Samples were then centrifuged, washed, and $30 \mu \mathrm{l}$ of Laemmli sample buffer was added to the PRO-A bead slurry. Samples were heated at $100^{\circ} \mathrm{C}$ for 5 minutes. Ten microliters of sample was loaded in duplicate onto a SDS-PAGE gel (10\% for IR- $\beta$ pY, $7.5 \%$ for IRS- 1 pY and IRS-1 pS 307). Membranes were incubated overnight at $4^{\circ} \mathrm{C}$ with anti-pY (Cat\#6-247, UBT) for IR- $\beta$ pY and IRS-1 pY and anti-IRS-1 pS 307 (Cat\#07-247, Millipore) for IRS-1 pS. 
Co-immunoprecipitation of IRS-1 pY with IR- $\beta$-Sixty microliters of PRO-A bead slurry were incubated with $5 \mu \mathrm{g}$ of anti-IR- $\beta$ (Cat\# 07-724, Millipore) antibody overnight at $4{ }^{\circ} \mathrm{C}$ with rotation. Following the overnight incubation PRO-A/antibody complex was washed 3 times with Phosphate Buffered Saline (PBS). The PRO-A/antibody complex was then incubated overnight with rotation at $4^{\circ} \mathrm{C}$ with $500 \mu \mathrm{g}$ of lysate protein followed by washing once with PBS, once with $2 \%$ Triton X-PBS and a final PBS wash before the addition of $30 \mu \mathrm{l}$ of Laemmli sample buffer. Samples were heated at $100^{\circ} \mathrm{C}$ for 5 minutes. Ten microliters of eluted sample were loaded in duplicate and subjected to SDS-PAGE run under reducing conditions on a 7.5\% resolving gel. Resolved proteins were transferred to PVDF membranes, blocked, and incubated overnight at $4^{\circ} \mathrm{C}$ with anti-phospho-IRS-1 (Cat\# 07-848, Millipore).

IRS-1 Associated PI3-K Activity-Between 100 and 150 mg of insulin-stimulated RG were weighed frozen and homogenized as previously described. The supernatant was collected, quantified for protein and IRS-1 associated PI 3-kinase activity was determined as we have detailed previously (Krisan et al., 2004).

\section{Pro-inflammatory Signaling and SOCS-3}

Skeletal Muscle TNF- $\alpha-$ TNF- $a$ concentration was determined in lysate samples. Sixty microliters of PRO-A bead slurry were incubated with $5 \mu \mathrm{g}$ of anti-TNF- $a$ antibody (Cat\# ARC3012, Biosource, Camarillo, CA) overnight at $4^{\circ} \mathrm{C}$ with rotation. Following the overnight incubation, the PRO-A/antibody complex was washed 3 times with PBS. Eight hundred micrograms of lysate protein were then incubated overnight at $4^{\circ} \mathrm{C}$ with rotation with the PRO-A/antibody complex. Following the overnight incubation, the bead slurry was washed once with PBS, once with $2 \%$ Triton X-PBS and a final PBS wash before the addition of $30 \mu \mathrm{l}$ of Laemmli solution. Ten microliters of supernatant were loaded in duplicate and subjected to SDS-PAGE run under reducing conditions on a $15 \%$ resolving gel. Resolved proteins were transferred to PVDF membranes, blocked, and incubated overnight at $4^{\circ} \mathrm{C}$ with affinity purified, rabbit polyclonal anti-TNF-a (Cat\# ARC3012, Biosource) primary antibody.

\section{Analysis of Select Components of the IкB/NF-кB Pro-Inflammatory Pathway}

\section{Western Blot Analysis of IKK $\alpha$, IKK $\beta$, IKK $\alpha / \beta$ pS 176/180, and IKB $\alpha-O n e$} hundred micrograms of muscle lysate protein was subjected to SDS-PAGE run under reducing conditions on a 7.5\% resolving gel and transferred to PVDF membranes. The PVDF membranes were blocked, and then incubated with either anti-IKKa (Cat\# 2682, Cell Signaling Technology, Beverly, MA), anti-IKK $\beta$ (Cat\# 2370, Cell Signaling Technology), anti-IKKa/ $\beta$ pS 176/180 (Cat\# 2694, Cell Signaling Technology), or anti-IкBa (Cat\# 4812, Cell Signaling Technology) primary antibody solutions.

IkBa Serine Phosphorylation-Phosphorylation of I $\mathrm{kBa}$ pS 32/36 was determined using immunoprecipitation followed by Western blotting. Lysate protein samples $(800 \mu \mathrm{g})$ were incubated with $5 \mu \mathrm{g}$ of anti-IxBa pS 32/36 (Cat\# 9246L, Cell Signaling Technology) at $4^{\circ} \mathrm{C}$. Following an overnight incubation, $60 \mu \mathrm{l}$ of PRO-A bead slurry was added to the samples and incubated for 1.5 hours at $4^{\circ} \mathrm{C}$ with rotation. Samples were then centrifuged, washed, and $30 \mu \mathrm{l}$ of Laemmli sample buffer was added to PRO-A bead slurry. Samples were heated at $100^{\circ} \mathrm{C}$ for 5 minutes. Ten microliters of sample was loaded in duplicate onto a 10\% SDS-PAGE gel. Proteins were resolved and transferred as described above. Membranes were incubated with anti-IкBa pS 32/36 (Cat\# 9246L, Cell Signaling Technology) primary antibody overnight at $4^{\circ} \mathrm{C}$. 
JNK 1 and JNK 2/3 Protein Concentration-Skeletal muscle lysate samples were used for western blot analysis of JNK1 and JNK 2/3. Seventy five micrograms of muscle lysate protein were subjected to SDS-PAGE run under reducing conditions on a $12.5 \%$ resolving gel and transferred to PVDF membranes. The PVDF membranes were blocked, and incubated with anti-JNK (Cat\# 9252, Cell Signaling Technology) primary antibody.

JNK 1 and JNK 2/3 Phosphorylation-Skeletal muscle lysate samples were used for western blot analysis of Phospho-JNK 1 and Phospho-JNK 2/3. Seventy five micrograms of muscle lysate protein were subjected to SDS-PAGE run under reducing conditions on a $12.5 \%$ resolving gel and transferred to PVDF membranes. The PVDF membranes were blocked, and incubated with anti-JNK pT183/Y185 (Cat\# 9255, Cell Signaling Technology) primary antibody solution.

SOCS-3 Protein Concentration-Fifty micrograms of skeletal muscle lysate protein were subjected to SDS-PAGE run under reducing conditions on a 15\% resolving gel. Resolved proteins were transferred to PVDF membranes, blocked overnight at $4{ }^{\circ} \mathrm{C}$ with $5 \%$ bovine serum albumin-TTBS, and then incubated with affinity purified rabbit polyclonal anti-SOCS-3 (Cat\# sc-9023, Santa Cruz Biotechnology (SCBT), Santa Cruz, CA) primary antibody solutions for 2 hours at room temperature.

Co-immunoprecipitation of SOCS-3 with IR- $\beta$ and IRS-1-Lysate samples (800 $\mu \mathrm{g}$ of protein) were subjected to immunoprecipitation with $8 \mu \mathrm{g}$ of either anti- IR- $\beta$ (Cat\# 07-724, Millipore) or anti-IRS-1 (Cat\# 06-526, Millipore) antibody. Immunocomplexes were allowed to form overnight at $4^{\circ} \mathrm{C}$ with rotation. Following an overnight incubation samples were loaded with $80 \mu \mathrm{l}$ of PRO-A bead slurry and rotated for 3 hours at $4^{\circ} \mathrm{C}$. Samples were then centrifuged, washed, and $30 \mu \mathrm{l}$ of Laemmli sample buffer was added to the PRO-A bead slurry and heated at $100^{\circ} \mathrm{C}$ for 5 minutes. Ten microliters of eluted sample were loaded in duplicate onto a $12.5 \%$ SDS-PAGE resolving gel. Following electrophoresis, resolved proteins were transferred onto PVDF membranes, blocked, and then probed with anti-SOCS-3 (Cat\# sc-9023, SCBT) primary antibody for 2 hours.

\section{Statistical Analysis}

An analysis of variance (ANOVA) was used on all variables to determine whether significant differences existed between groups. When a significant $F$-ratio was obtained, a Tukey HSD post hoc test was used to identify statistically significant differences $(p<0.05)$ among the means. Statistical analyses were performed using JMP software (SAS Institute Inc., Cary, $\mathrm{NC}$ ), and all values are expressed as means $\pm \mathrm{SE}$.

\section{RESULTS}

Body Mass

The obese Zucker rats were significantly $(\mathrm{p}<0.05)$ heavier $(375.6 \pm 7.4 \mathrm{~g})$ compared to the lean Zucker rats $(211.2 \pm 11.4 \mathrm{~g})$.

\section{Skeletal Muscle 3-MG Transport}

Insulin stimulated rates of 3-MG transport of the lean animals were greater $(\mathrm{p}<0.05)$ than that of the obese animals in both the RG (lean: $2.83 \pm 0.60 \mu \mathrm{mol} / \mathrm{g} / \mathrm{h}$ vs. obese: $0.90 \pm 0.18$ $\mu \mathrm{mol} / \mathrm{g} / \mathrm{h}$ ) and RQ (lean: $3.91 \pm 0.65 \mu \mathrm{mol} / \mathrm{g} / \mathrm{h}$ vs. obese: $1.32 \pm 0.35 \mu \mathrm{mol} / \mathrm{g} / \mathrm{h}$ ). 


\section{Insulin Signaling Cascade}

IR- $\beta$ protein content and IR- $\beta$ subunit tyrosine phosphorylation (Fig. 1A) were reduced $(\mathrm{p}<0.05)$ in the obese Zucker rat. IRS-1 protein concentration (Fig. 1B) was similar between the lean and obese animals while IRS-1 pY (Fig. 1B) was reduced $37 \%(\mathrm{p}<0.05)$ and IRS-1 pS (Fig. 1B) was elevated $47 \%(\mathrm{p}<0.05)$ in the obese animals. IRS-1 coimmunoprecipitation with IR- $\beta$ (Fig. 1C) was reduced 56\% (p<0.05) and IRS-1 associated PI3-K activity (Fig. 1D) was reduced $44 \%(\mathrm{p}<0.05)$ in the obese animals.

\section{Pro-inflammatory Signaling Cascade}

Skeletal muscle TNF- $a$ concentration was significantly $(p<0.05)$ elevated by $42 \%$ in the obese animals compared to lean animals (Fig. 2A). Although IKKa and IKK $\beta$ protein concentration was similar between the lean and obese animals (Fig. 2B), IKKa/ $\beta$ serine phosphorylation was significantly $(\mathrm{p}<0.05)$ increased in the obese animals (Fig. $2 \mathrm{~B})$. I $\mathrm{KBa}$ protein concentration (Fig. 2C) was decreased by $53 \%$ (p<0.05) and IкBa serine phosphorylation was increased $180 \%(\mathrm{p}<0.05)$ in obese animals (Fig. $2 \mathrm{C})$.

JNK 1 and JNK 2/3 protein concentration was similar among the lean and obese animals (Fig. 2D), but phosphorylation of JNK 1(Fig. 2D) and JNK 2/3 was increased $(\mathrm{p}<0.05)$ by $40 \%$ and $28 \%$, respectively in obese animals.

Obese animals exhibited a 228\% $(\mathrm{p}<0.05)$ increase in SOCS-3 protein concentration (Fig. 3 ), and SOCS-3 co-immunoprecipitation with IR- $\beta$ and IRS-1 (Fig. 3 ) was increased (71\% and $44 \%$, respectively) in obese animals compared to lean animals.

\section{DISCUSSION}

In this investigation, we showed that skeletal muscle of the obese Zucker rat exhibited significantly impaired carbohydrate metabolism as evidenced by decreased rates of insulinstimulated 3-MG transport when compared to their lean littermates. These findings are consistent with previous investigations that also have shown decreased insulin-stimulated glucose transport rates in the skeletal muscle of the obese Zucker rat (Banks et al., 1992; Brozinick et al., 1994). However, it has not been clearly established why 3-MG transport is decreased in this model of insulin resistance, although it has been postulated by Christ et al. (Christ et al., 2002) and Jiang et al. (Jiang G et al., 2002) that a reduction in PI3-K activity leads to peripheral impairments in the insulin signaling cascade that result in the reduced insulin-stimulated 3-MG transport rates. In agreement with these reports we also showed reduced insulin-stimulated PI3-K activity in the obese Zucker rat. Thus, it was of interest to investigate potential mechanisms that might reduce insulin-stimulated PI3-K activity in the skeletal muscle of the obese Zucker rat.

Pro-inflammatory cytokines, especially those linked to the IKK $\beta / \mathrm{NFKB}$ cascade, have been implicated as a potential trigger of PI3-K inhibition. Activated IKK $\beta$ has been shown to directly phosphorylate IRS-1 on serine 307 (Gao et al., 2002), and increased IRS-1 serine phosphorylation leads to decreased PI3-K activation and inhibition of the insulin signaling cascade (Hirosumi et al., 2002; Kim et al., 2004; Um et al., 2004; Yu et al., 2002).

Confirming the importance of the IKK $\beta / \mathrm{NFKB}$ cascade in the development of insulin resistance are previous experiments that demonstrated that IKK $\beta$ knockout mice remain insulin sensitive during lipid infusion (Kim et al., 2001; Yu et al., 2002). Also, chronic administration of high doses of salicylates inhibit IKK $\beta$ and improve insulin sensitivity in human subjects (Hundal et al., 2002) and obese Zucker fa/fa rats (Yu et al., 2002), while heterozygous $\left(\mathrm{IKK} \beta^{+/-}\right)$mice do not develop insulin resistance in response to high-fat feeding (Kim et al., 2001). In this investigation, we showed that IKKa and IKK $\beta$ concentration was similar between obese and lean animals, but the obese Zucker rat 
exhibited significantly higher IKKa/ $\beta$ serine phosphorylation, signifying an increased activation of IKKa and IKK $\beta$. This is significant since increased IKK $\beta$ activity could account for the increased IRS-1 serine phosphorylation (Jiang et al., 2004), which we observed in the skeletal muscle of the obese Zucker rats.

In order to provide further evidence for the activation of the IKK $\beta / \mathrm{NF} \kappa \mathrm{B}$ cascade we measured IxBa protein concentration and serine phosphorylation. It is well known that when activated IKK $\beta$ phosphorylates I $\mathrm{KBa}$ on serine residues, causing a dissociation of $\mathrm{I} \kappa \mathrm{Ba} / \mathrm{NF} \kappa \mathrm{B}$ complex and allowing NFkB to translocate into the cell nucleus while phosphorylated $\mathrm{I} \times \mathrm{Ba}$ is targeted for proteasomal degradation. Corroborating the activation of the IKK $\beta / N F \kappa B$ cascade are our observations that the obese Zucker rat exhibited a significant increase in I $\mathrm{KBa}$ serine phosphorylation, and as expected, a decrease in $\mathrm{I} \kappa \mathrm{Ba}$ concentration. Of note, our findings on the IKK $\beta / \mathrm{NF} \kappa \mathrm{B}$ cascade in the obese Zucker rat are not unique to this rodent model of insulin resistance as they parallel our findings in the highfat fed rat, an environmental model of insulin resistance (Yaspelkis et al., 2009). This is interesting as it might indicate a common underlying mechanism of PI3-K inhibition regardless as to how skeletal muscle insulin resistance is initiated.

The next line of inquiry was to determine a possible mechanism responsible for the increased serine phosphorylation of IKKa and IKK $\beta$. It has been previously reported that $\mathrm{TNFa}$, a pro-inflammatory cytokine, can increase IKK activity (DiDonato et al., 1997). The potential role of TNFa contributing to insulin resistance has developed from a number of studies that have shown that a reduction in TNFa concentration improves insulin sensitivity (Arkan et al., 2005; Inoue et al., 2006; Kim et al., 2001; Yu et al., 2002). Although it has been shown that obese Zucker rats have elevated TNFa protein concentration in blood serum and smooth muscle, to the best of our knowledge TNFa protein concentration has not been previously reported in the skeletal muscle of the obese Zucker rat. In the present investigation, we found TNFa concentration was significantly increased in the skeletal muscle of the obese compared to the lean Zucker rat. This observation is of note as it has been reported that elevated TNFa protein levels may increase IKK activation (Yu et al., 2002). In addition to activating the IKK $\beta / \mathrm{NFKB}$ pathway, TNFa has also been shown to activate the JNK pathway (Ichijo, 1999; Kyriakis and Avruch, 2001). When activated JNK has been found to increase IRS-1 serine phosphorylation (Aguirre et al., 2000; Hirosumi et al., 2002; Prada et al., 2005). We evaluated expression and phosphorylation of JNK 1 and JNK 2/3 in the insulin-stimulated skeletal muscle of obese and lean Zucker rats. JNK protein concentration was similar in the RQ when comparing the lean and obese rats. In contrast, Katta et al. (Katta et al., 2008) have noted that JNK 1, and JNK 1 and 2 are elevated in obese Zucker plantaris and soleus, respectively. Nevertheless we did find that JNK 1 and JNK 2/3 phosphorylation was significantly elevated in the skeletal muscle of the obese Zucker rat, indicating increased JNK activity. Consequently, the increased JNK activation could also partially account for the increased IRS-1 serine phosphorylation and contribute to decreased insulin-stimulated PI3-K activity. However, it should be noted that increased IRS-1 serine phosphorylation may not be the only mechanism responsible for decreasing PI3-K activity.

A number of investigations have implicated SOCS-3 as a molecule that might also reduce insulin-stimulated PI3-K activity (Grimble, 2002; Ronn et al., 2007; Ueki et al., 2004a). In support of these findings, we show in the present investigation that SOCS-3 protein expression and SOCS-3 co-immunoprecipitation with both the IR- $\beta$ subunit and IRS- 1 was significantly elevated, while IR- $\beta$ co-immunoprecipitation with IRS- 1 was significantly reduced in the skeletal muscle of the obese Zucker rat. It has been reported that TNFa induces SOCS-3 expression (Grimble, 2002). As TNFa was elevated in the skeletal muscle of the obese Zucker rats it may have contributed to increasing SOCS-3 expression in these animals. In addition, our observations are in agreement with previous reports that show that 
SOCS-3 is able to bind to the IR- $\beta$ subunit in 3T3-L1 adipocytes and COS7 cells thereby blocking the main IRS-1 binding site on the IR- $\beta$ subunit (Emanuelli et al., 2001; Emanuelli et al., 2000). Additionally, Rui et al. (Rui et al., 2002) showed that SOCS-3 can bind to IRS-1 in HEK293 cells and hepatocytes obtained from C57BL/6 mice. Accordingly, our data indicate that increased co-localization of SOCS-3 with both IR- $\beta$ and IRS- 1 may create a physical barrier that prevents IR- $\beta$ from interacting with IRS-1. The inability of IRS- 1 to interact with IR- $\beta$ due to steric hindrance may potentially account for the reduction in PI3-K activity in the skeletal muscle of the obese Zucker rat. Of considerable interest, our findings on SOCS-3 in the Zucker rat are not unique to this model of insulin resistance as they are also in agreement with our recent findings in the high-fat fed rat (Jiang et al., 2004; Yaspelkis et al., 2009). Taken together, this suggests that the inhibition of IRS-1 colocalization with IR- $\beta$ by SOCS- 3 might be a common mechanism responsible for the reduction in insulin-stimulated skeletal muscle PI3-K activity in insulin resistant skeletal muscle regardless how insulin resistance develops.

\section{CONCLUSIONS}

We showed that select components of the pro-inflammatory pathway, TNFa, IKK $\beta$ and JNK were altered and may contribute to increasing IRS- 1 serine phosphorylation, which inhibits insulin-stimulated PI3-K activity in obese Zucker rat skeletal muscle. Additionally, we found that SOCS- 3 concentration and co-localization with both the IR- $\beta$ and IRS- 1 is increased in the obese Zucker rat. This possibly resulted in steric hindrance that reduces colocalization of IRS- 1 with IR- $\beta$ and contributes to reducing insulin-stimulated PI3-K activity. The significance of our findings is that the identified mechanisms of PI3-K inhibition in the skeletal muscle of the obese Zucker rat parallel our findings on the IKK $\beta$ / $\mathrm{NFKB}$ cascade, TNFa protein concentration and the SOCS-3 pathway previously made in the high-fat fed rat (Yaspelkis et al., 2009). Taken together, these data indicate that the underlying causes of impairment of the insulin-signaling cascade may be independent of how skeletal muscle insulin resistance develops.

\section{Acknowledgments}

This study was supported by a grant from the National Institutes of Health (DK-57625)

\section{References}

Aguirre V, Uchida T, Yenush L, Davis R, White MF. The c-Jun NH(2)-terminal kinase promotes insulin resistance during association with insulin receptor substrate-1 and phosphorylation of Ser(307). J Biol Chem. 2000; 275:9047-9054. [PubMed: 10722755]

Arkan MC, Hevener AL, Greten FR, Maeda S, Li ZW, Long JM, Wynshaw-Boris A, Poli G, Olefsky JM, Karin M. IKK-beta links inflammation to obesity-induced insulin resistance. Nat Med. 2005; 11:191-198. [PubMed: 15685170]

Banks EA, Brozinick JT Jr, Yaspelkis BB III, Kang HY, Ivy JL. Muscle glucose transport, GLUT4 content and degree of exercise training in obese Zucker rats. Am J Physiol Endocrinol Metab. 1992; 263:E1010-E1015.

Brozinick JT Jr, Etgen GJ Jr, Yaspelkis BB III, Ivy JL. The effects of muscle contraction and insulin on glucose-transporter translocation in rat skeletal muscle. Biochem J. 1994; 297:539-545. [PubMed: 8110191]

Christ CY, Hunt D, Hancock J, Garcia-Macedo R, Mandarino LJ, Ivy JL. Exercise training improves muscle insulin resistance but not insulin receptor signaling in obese Zucker rats. J Appl Physiol. 2002; 92:736-744. [PubMed: 11796688]

DiDonato JA, Hayakawa M, Rothwarf DM, Zandi E, Karin M. A cytokine-responsive IkappaB kinase that activates the transcription factor NF-kappaB. Nature. 1997; 388:548-554. [PubMed: 9252186] 
Emanuelli B, Peraldi P, Filloux C, Chavey C, Friedinger K, Hilton DJ, Hotamisligil GS, Van Obberghen E. SOCS-3 inhibits insulin signaling and is up-regulated in response to tumor necrosis factor-alpha in the adipose tissue of mice. J Biol Chem. 2001; 276:47944-47949. [PubMed: 11604392]

Emanuelli B, Peraldi P, Filloux C, Sawka-Verhelle D, Hilton D, Van Obberghen E. SOCS-3 is an insulin-induced negative regulator of insulin signaling. J Biol Chem. 2000; 275:15985-15991. [PubMed: 10821852]

Gao Z, Hwang D, Bataille F, Lefevre M, York D, Quon MJ, Ye J. Serine phosphorylation of insulin receptor substrate 1 by inhibitor kappa B kinase complex. J Biol Chem. 2002; 277:48115-48121. [PubMed: 12351658]

Grimble RF. Inflammatory status and insulin resistance. Curr Opin Clin Nutr Metab Care. 2002; 5:551-559. [PubMed: 12172480]

Hansen PA, Han DH, Marshall BA, Nolte LA, Chen MM, Mueckler M, Holloszy JO. A high fat diet impairs stimulation of glucose transport in muscle. Functional evaluation of potential mechanisms. J Biol Chem. 1998; 273:26157-26163. [PubMed: 9748297]

Herr HJ, Bernard JR, Reeder DW, Rivas DA, Limon JJ, Yaspelkis BB III. Insulin-stimulated plasma membrane association and activation of Akt2 and, $\operatorname{aPKC} \zeta$ and $\lambda$ in high fat fed rodent skeletal muscle. J Physiol. 2005; 565:627-636. [PubMed: 15802290]

Hirosumi J, Tuncman G, Chang LF, Gorgun CZ, Uysal KT, Maedda K, Karin M, Hotamisligil GS. A central role for JNK in obesity and insulin resistance. Nature. 2002; 420:333-336. [PubMed: 12447443]

Hundal RS, Petersen KF, Mayerson AB, Randhawa PS, Inzucchi S, Shoelson SE, Shulman GI. Mechanism by which high-dose aspirin improves glucose metabolism in type 2 diabetes. J Clin Invest. 2002

Ichijo H. From receptors to stress-activated MPA kinases. Oncogene. 1999; 18:6087-6093. [PubMed: 10557099]

Inoue N, Nagao K, Wang YM, Noguchi H, Shirouchi B, Yanagita T. Dietary conjugated linoleic acid lowered tumor necrosis factor-alpha content and altered expression of genes related to lipid metabolism and insulin sensitivity in the skeletal muscle of obese Zucker rats. J Agric Food Chem. 2006:54. [PubMed: 16390177]

Ivy JL, Brozinick JT Jr, Torgan CE, Kastello GM. Skeletal muscle glucose transport in obese Zucker rats after exercise training. J Appl Physiol. 1989; 66:2635-2641. [PubMed: 2745325]

Jiang G, Dallas-Yang Q, Li Z, Szalkowski D, Liu F, Shen X, Wu M, Zhou G, Doebber T, Berger J, Moller DE, Zhang B. Potentiation of insulin signaling in tissues of Zucker obese rats after acute and long-term treatment with PPARgamma agonists. Diabetes. 2002; 51:2412-2419. [PubMed: 12145152]

Jiang G, Dallas-Young Q, Biswas S, Li Z, Zhang BB. Rosiglitazone, an agonist of peroxisomeproliferator-activated receptor gamma PARgamma), decreases inhibatory serine phsophorylation of IRS1 in vitro and in vivo. Biochem J. 2004; 15:339-346. [PubMed: 14556646]

Katta A, Preston DL, Karkala SK, Asano S, Meduru S, Mupparaju SP, Yokochi E, Rice KM, Desai $\mathrm{DH}$, Blough ER. Diabetes alters contraction-induced mitogen activated protein kinase activation in the rat soleus and plantaris. Exp Diabetes Res. 2008; 2008:738101. [PubMed: 18551177]

Kim JK, Fillmore JJ, Sunshine MJ, Albrecht B, Higashimori T, Kim DW, Liu ZX, Soos TJ, Cline GW, O'Brien WR, Littman DR, Shulman GI. PKC-theta knockout mice are protected from fat-induced insulin resistance. J Clin Invest. 2004; 114:823-827. [PubMed: 15372106]

Kim JK, Kim Y-J, Fillmore JJ, Chen Y, Moore I, Lee J, Yuan M, Li ZW, Karin M, Perret P, Shoelson SE, Shulman GI. Prevention of fat-induced insulin resistance by salicylate. J Clin Invest. 2001; 108:437-446. [PubMed: 11489937]

Kim YB, Peroni OD, Franke TF, Kahn BB. Divergent regulation of Akt1 and Akt2 isoforms in insulin target tissues of obese Zucker rats. Diabetes. 2000; 49:1569-1575.

Krisan AD, Collins DE, Crain AM, Kwong CC, Singh MK, Bernard JR, Yaspelkis BB III. Resistance training enhances components of the insulin signaling cascade in normal and high-fat-fed skeletal muscle. J Appl Physiol. 2004; 96:1691-1700. [PubMed: 14707149] 
Kyriakis JM, Avruch J. Mammalian mitogen-activated protein kinase signal transduction pathways activataed by stress and inflammation. Physiol Rev. 2001; 81:807-869. [PubMed: 11274345]

Lessard SJ, Rivas DA, Chen ZP, Bonen A, Febbraio MF, Reeder DW, Kemp BE, Yaspelkis BB III, Hawley JA. Tissue-specific effects of Rosiglitazone and exercise in the treatment of lipid-induced insulin resistance. Diabetes. 2007; 56:1856-1864. [PubMed: 17440174]

Prada PO, Zecchin HG, Gasparetti AL, Torsoni MA, Ueno M, Hirata AE, Corezola do Amaral ME, Hoer NF, Boschero AC, Saad MJ. Western diet modulates insulin signaling, c-Jun-N-terminal kinase activity, and insulin receptor substrate- $1^{\text {ser307 }}$ phosphorylation in a tissue-specific fashion. Endocrinol. 2005; 146:1576-1587.

Ronn SG, Billestrup N, Mandrup-Poulsen T. Diabetes and suppressors of cytokine signaling proteins. Diabetes. 2007; 56:541-548. [PubMed: 17259405]

Ropelle ER, Pauli JR, Prada PO, de Souza CT, Picardi PK, Faria MC, Cintra DE, de Fernanda A, Fernandes M, Flores MB, Vellose LA, Saad MJA, Carvalheira JBC. Reversal of diet-induced insulin resistance with a single bout of exercise in the rat: the role of PTP1B and IRS-1 serine phosphorylation. J Physiol. 2006; 577:997-1007. [PubMed: 17008371]

Ruderman NB, Houghton CRS, Helms R. Evaluation of the isolated perfused rat hindquarter for the study of muscle metabolism. Biochem J. 1971; 124:639-651. [PubMed: 5135248]

Rui L, Yuan M, Frantz D, Shoelson S, White M. SOCS-1 and SOCS-3 block insulin signaling by ubiquitin-mediated degradation of IRS1 and IRS2. J Biol Chem. 2002; 277:42394-42398. [PubMed: 12228220]

Singh MK, Krisan AD, Crain AM, Collins DE, Yaspelkis BB III. High-fat diet and leptin treatment alter skeletal muscle insulin-stimulated phosphatidylinositol 3-kinase activity and glucose transport. Metabol. 2003; 52:1196-1205.

Steinberg GR, Smith AC, Wormald S, Malenfant P, Collier C, Dyck DJ. Endurance training partially reverses dietary-induced leptin resistance in rodent skeletal muscle. Am J Physiol Endocrinol Metab. 2004; 286:E57-E63. [PubMed: 14662513]

Ueki K, Kondo T, Kahn CR. Suppressor of cytokine signaling 1 (SOCS-1) and SOCS-3 cause insulin resistance through inhibition of tyrosine phosphorylation of insulin receptor substrate proteins by discrete mechanisms. Mol Cell Biol. 2004a; 24:5434-5446. [PubMed: 15169905]

Ueki K, Kondo T, Tseng YH, Kahn CR. Central role of suppressors of cytokine signaling proteins in hepatic steatosis, insulin resistance, and the metabolic syndrome in the mouse. Proc Natl Acad Sci. 2004b; 101:10422-10427. [PubMed: 15240880]

Um SH, Frigerio F, Watanaabe M, Picard F, Joaqui M, Sticker M, Fumagalli S, Allegrini PR, Kozma SC, Auwerx J, Thomas G. Absence of S6K1 protects against age- and diet-induced obesity while enhancing insulin sensitivity. Nature. 2004; 431:200-2005. [PubMed: 15306821]

Yaspelkis BB III, Davis JR, Saberi M, Smith TL, Jazayeri R, Singh M, Fernandez V, Trevino B, Chinookoswong N, Wang J, Shi ZQ, Levin N. Leptin administration improves skeletal muscle insulin responsiveness in diet-induced insulin-resistant rats. Am J Physiol Endocrinol Metab. 2001; 280:E130-E142. [PubMed: 11120667]

Yaspelkis BB III, Kvasha IA, Figueroa TY. High-fat feeding increases insulin receptor and IRS-1 coimmunoprecipitation with SOCS-3, IKKa/ $\beta$ phosphorylation and decreases PI-3 kinase activity in muscle. Am J Physiol Regulatory Integrative Comp Physiol. 2009; 296:R1709-R1715.

Yaspelkis BB III, Lessard SJ, Reeder DW, Limon JJ, Saito M, Rivas DA, Kvasha I, Hawley JA. Exercise reverses high-fat diet-induced impairments on compartmentalization and activation of components of the insulin signaling cascade in skeletal muscle. Am J Physiol Endocrinol Metabol. 2007; 293:E941-E949.

Yaspelkis BB III, Singh MK, Krisan AD, Collins DE, Kwong CC, Bernard JR, Crain AM. Chronic leptin treatment enhances insulin-stimulated glucose disposal in skeletal muscle of high-fat fed rodents. Life Sci. 2004; 74:1801-1816. [PubMed: 14741737]

Yu CL, Chen Y, Cline GW, Zhang DY, Zong HH, Wang YL, Bergeron R, Kim JK, Cushman SW, Cooney GJ, Atcheson B, White MF, Kraegen EW, Shulman GI. Mechanism by which fatty acids inhibit insulin activation of insulin receptor substrate-1 (IRS-1)-associated phosphatidylinositol 3kinase activity in muscle. J Biol Chem. 2002; 277:50230-50236. [PubMed: 12006582] 
A

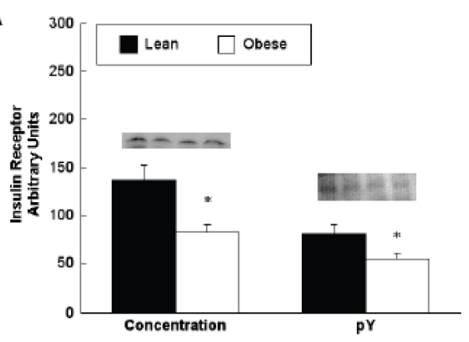

$\mathrm{C}$

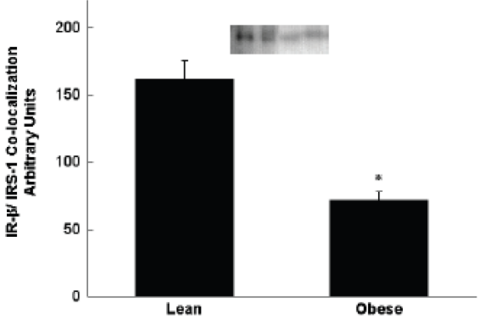

B

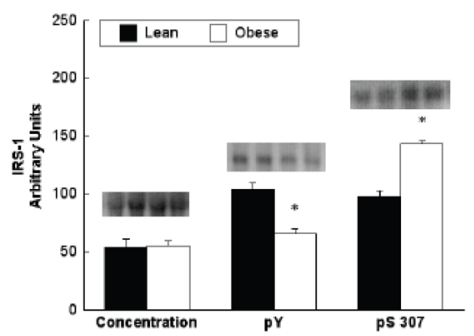

D

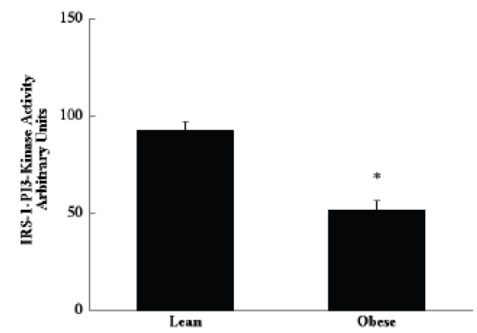

Figure 1.

IR- $\beta$ subunit protein concentration and IR- $\beta$ tyrosine phosphorylation (pY) (A), IRS-1 protein concentration, IRS-1 tyrosine phosphorylation (pY) and IRS-1 serine 307 phosphorylation (pS) (B), co-immunoprecipitation of IRS-1 with IR- $\beta$ subunit (C), and insulin-stimulated IRS-1 associated Phosphoinositol 3-kinase (PI3-K) activity (D) in skeletal muscle obtained from lean $(n=8)$ and obese $(n=8)$ animals. *, Significantly different from lean animals $(\mathrm{p}<0.05)$. Autoradiograph lanes $1-2$ are representative lean, and lanes 3-4 are representative obese samples. Values are expressed as means \pm SE. 
A

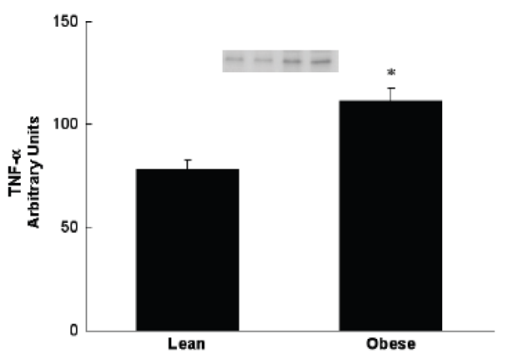

C

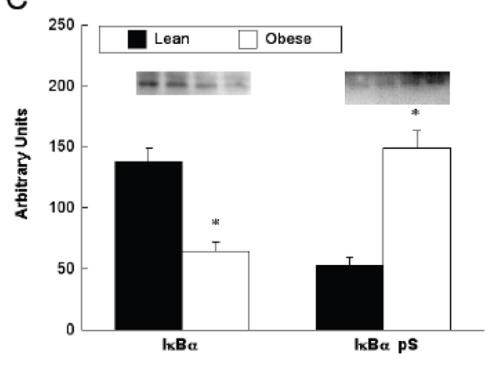

B

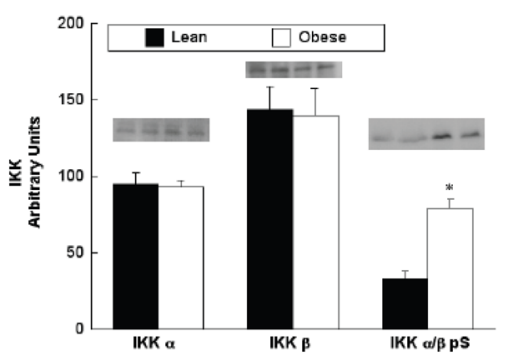

D

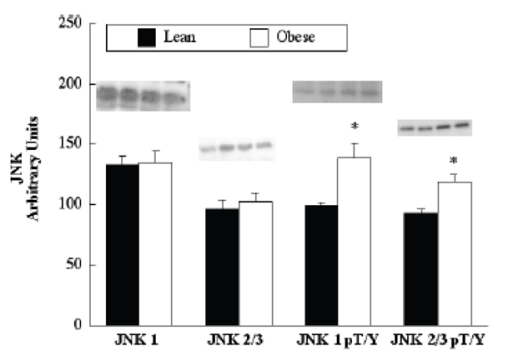

Figure 2.

TNF-a protein concentration (A), IKKa, IKK $\beta$ protein concentration and IKK $a / \beta$ serine phosphorylation $(\mathrm{pS})(\mathbf{B}), \mathrm{IkBa}$ protein concentration and $\mathrm{IkBa}$ serine phosphorylation $(\mathrm{pS})$ (C), and JNK 1, JNK 2/3 protein concentration, Phospho-JNK 1 and Phospho-JNK 2/3 (D) in skeletal muscle obtained from lean $(n=8)$ and obese $(n=8)$ animals. *, Significantly different from lean animals ( $\mathrm{p}<0.05)$. Autoradiograph lanes $1-2$ are representative lean, and lanes 3-4 are representative obese samples. Values are expressed as means \pm SE. 


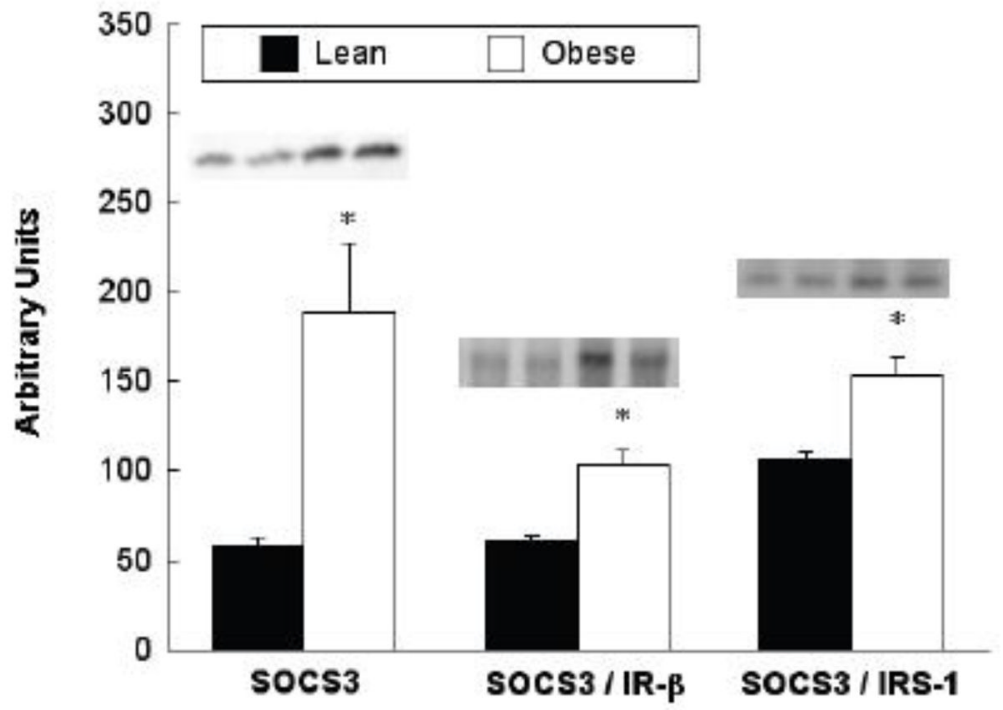

Figure 3.

SOCS-3 protein concentration, SOCS-3 co-immunoprecipitation with IR- $\beta$ and SOCS-3 coimmunoprecipitation with IRS-1 in skeletal muscle obtained from lean $(n=8)$ and obese $(n$ $=8$ ) animals. *, Significantly different from lean animals $(\mathrm{p}<0.05)$. Autoradiograph lanes $1-$ 2 are representative lean, and lanes 3-4 are representative obese samples. Values are expressed as means $\pm \mathrm{SE}$. 